\title{
The effects of low dose capsaicin on substance $P$ expression in rat duodenum
}

\author{
Cansel Güzin ÖZGÜDEN AKKOÇ, Tuncay İLHAN, Sabire PEKER, Berrin ZIK
}

Uludağ University, Faculty of Veterinary Medicine, Department of Histology and Embryology, Bursa, Turkey.

\begin{abstract}
Summary: The aim of the present study was to investigate effects of low dose capsaicin (CAP) on substance P (SP) expression and histomorphometric properties of duodenum. In this study, 21-day-old rats were divided into three groups as control, CAP-treated and vehicle. The control group remained without any treatment. $0.5 \mathrm{mg} / \mathrm{kg}$ CAP prepared in a solvent and injected subcutaneously to CAP-treated group and vehicle group was injected with only solvent for 20 days. All rats were weighed daily. At the end of the experiment, tissue samples were collected and Crossman's triple staining was used for histomorphometric examinations and labelled streptavidin-biotin immunohistochemical technique was used for SP expression. The body weight gain was lower in the CAP treated group but no significant differences between the groups. Low dose CAP did not alter the depth of crypt in the duodenum but the height of the villus was higher than the other group $(\mathrm{p}<0.05)$. In the CAP treated group, SP immunoreaction was stronger than the other groups in the surface epithelium, Lieberkühn crypts, in the Brunner's glands, smooth muscles layer, and the neurons of the myenteric plexus of the duodenum. Finally, low dose CAP, markedly stimulated expression of SP and also induced positively histomorphometric changes in the duodenum. As a result of low dose CAP treatment may play important role in epithelial cell functions and in the regulation of digestive system physiology.
\end{abstract}

Keywords: Capsaicin, duodenum, immunohistochemistry, rat, substance P.

\section{Düşük doz kapsaisinin rat duodenumunda substans $P$ ekspresyonu üzerine etkileri}

Özet: Sunulan çalışmanın amacı, düşük doz kapsaisinin (CAP) duodenumun histomorfometrik yapısı ve substans P (SP) ekspresyonu üzerine etkisini incelemektir. Çalışmada kullanılan ratlar (21 günlük), kontrol grubu, CAP enjekte edilen grup ve çözücü solüsyon enjekte edilen olmak üzere üç gruba ayrıldı. Kontrol grubuna enjeksiyon yapılmadı. 20 gün boyunca CAP grubuna çözücü solüsyon içerisinde hazırlanan $0.5 \mathrm{mg} / \mathrm{kg}$ kapsaisin, taşı1cı grubuna ise sadece çözücü solüsyon subkutan enjekte edildi. Ratlar her gün tartıldı. Deney sonrası dokular alınarak, doku kesitlerine histomorfometrik incemeler için Crossman'ın üçlü boyaması, SP ekspresyonunu belirlemek için ise işaretlenmiş streptavidin-biotin immunohistokimyasal tekniği uygulandı. CAP uygulanan grupta canlı ağırlık kazancı kontrol gruplarına göre düşüktü, fakat gruplar arasında istatiksel farklılık gözlenmedi. Düşük doz CAP duodenumun kript derinliğini etkilemezken, villus uzunluğu CAP uygulanan grupta diğer gruplara göre daha yüksek belirlendi $(\mathrm{p}<0.05)$. SP immunreaksiyonu duodenumun yüzey epitelinde, Lieberkühn kriptlerinde, ve Brunner bezlerinde, diğer gruplara göre CAP grubunda daha şiddetli gözlendi. Sonuç olarak düşük doz CAP, SP ekspresyonunu arttırdı ve duodenumda olumlu histomorfometrik değişiklere sebep oldu. Düşük doz CAP uygulaması sonucu artan SP ekspresyonu sindirim fizyolojisinin düzenlenmesinde önemli rol oynayabilir.

Anahtar sözcükler: Duodenum, immunohistokimya, kapsaisin, rat, substans P.

\section{Introduction}

Capsaicin (CAP), (8- methyl-N- vanillyl-6nonenamide), the main ingredient of hot chili peppers, selectively activates the peripheral terminal of sensory $\mathrm{C}$ and $\mathrm{A} \delta$ fibers, generally referred as polymodal nociceptors. CAP causes immediate and severe pain by exciting sensory neurons. The excitation of sensory neurons by CAP is mediated by the activation of CAP receptors (Vanilloid receptor-VR1) $(6,18)$. After initial excitation, sensory neurons do not respond to CAP after application of repeated or high doses of $\operatorname{CAP}(8,16)$.

CAP causes release of neuropeptides such as substance-P (SP) or calcitonin gene related peptide
(CGRP) from sensory nerve endings (12). CAP has various effects on the many systems such as cardiovascular, gastrointestinal systems. The most widespread use of CAP in neuroscience research is in chronic ablation or functional impairment of sensory Cfibres. CAP at a low dose stimulates sensory nerves, leading to the enhancement of gastric mucosal blood flow and the inhibition of gastric motor activity and gastric emptying (47). In contrast, a high dose of CAP shows neurotoxic effects, and induces an irreversible longstanding inactivation of the capsaicin-sensitive nerve endings with a loss of their sensory-afferent functions, and their ability to release of sensory neuropeptides (20). CAP 
has been shown to protect the gastric mucosa of animals and humans against various kinds of damage $(2,16,37)$. It is generally considered that CAP's effect results from the activation of sensory afferent neurons in the stomach, and is mediated by various physiological functions, such as mucosal blood flow, mucus secretion, and bicarbonate secretions $(1,25)$.

SP, a sensory neuropeptide with widespread effects in the central and peripheral nervous systems. SP has been identified in nerve endings throughout the gastrointestinal tract (22). In the gastrointestinal canal, SP has important roles in modulating gut motility, electrolyte secretion and blood flow $(19,21,30,48)$, and in takes part in the regulation of inflammation and immune responses (42).

CAP is not only used as a research tool or topical ointments for the treatment of pain, but also is consumed regularly by many people as hot chili pepper. The amount varies between the ethnical groups, but most people are exposed to low levels of CAP through diet. Although the effects of high doses of CAP are well established, the effect of repeated exposure to low doses of capsaicin is not known.

The aim of the present investigation was to identify effects of low-dose CAP $(0.5 \mathrm{mg} / \mathrm{kg})$ daily for 20 days on SP immunohistochemical expression, histological and also histomorphometric properties of duodenum in rat.

\section{Materials and Methods}

Animals: Thirty immature female Sprague-Dawley rats (21-day old) were used throughout the experiments. The rats were obtained from the Experimental Animals Breeding and Research Centre, Uludag University, Turkey. The animals were housed five per cage, in temperature controlled conditions of $\left(20-24^{\circ} \mathrm{C}\right)$, humidity (60-70\%), and lighting (12 h light/dark cycle), and were provided with feed and water ad libitum. The experimental protocols were approved by the Animal Care and Use Committee of the Uludag University and were in accordance with the National Institute of Health Guide for the Care and Use of Laboratory Animals.

Experimental protocol: The rats were randomly divided into three groups of 10 animals each group. The first group (control) remained without any treatment. The second group (CAP-treated) received subcutaneous injection of CAP (Sigma Chemical Co., USA) $(0.5 \mathrm{mg} / \mathrm{kg} / \mathrm{d})$, prepared in a solvent consisting of $10 \%$ of ethanol, $10 \%$ of Tween 80 , and $80 \%$ of distilled water, for 20 consecutive days, and the third group (vehicle treated) received an equal volume of the solvent in the same way used for CAP. All rats were weighed daily and following $20 \mathrm{~d}$ of CAP treatment, the animals were euthanatized by the injection of sodium pentobarbital and the abdominal walls were opened. The proximal part of the duodenum was removed and fixed in $10 \%$ formalin alcohol. Tissue samples were embedded in paraffin blocks according to routine histological procedures. Five micrometers thick sections were stained by the Crossman's triple stain for morphometric examination and duodenal mucosa morphology. Moreover, for SP localization, the sections were immunostained using labelled streptavidin biotin method as described (23).

Histological and morphometric analysis of the duodenum: The height of the villus and the depth of the crypts were measured by image analysis in Crossman's triple stained well-guided longitudinal paraffin sections and micrographs were taken with Nikon eclipse 80i microscope (Tokyo, Japan). The villus height was measured from the villus tip to villus-crypt junction level for randomly five villi, which has propria, per each section. Crypt depth was measured from the villus-crypt junction to the lower limit of the crypt. The villus height, crypt depth were measured twice per section and the mean was determined.

Immunohistochemistry: Polyclonal goat SP primary antibody (sc-9758, Santa Cruz Biotechnology Inc, CA, USA) was used for the SP immunostaining. The labelled streptavidin biotin was carried out by using the Histostain Plus Kit (Invitrogen, USA). Briefly, the sections were deparaffinized, hydrated, and put into $0.05 \%$ saponin for proteolysis. Endogenous peroxidase activity was blocked with 10 min incubation in $3 \% \mathrm{H}_{2} \mathrm{O}_{2}$ solution in distilled water. Non-specific antibody binding was reduced by the incubation of the tissues in non-immune serum blocking solution for $1 \mathrm{~h}$ at room temperature before application of the SP antibody. The sections were incubated overnight at $4^{\circ} \mathrm{C}$ with 1:1000 dilution of the SP antibody. The sections were incubated with biotinylated secondary rabbit antibody for 10 min followed by streptavidin conjugated to horseradish peroxidase for $10 \mathrm{~min}$ at room temperature. Finally, 3.3'-diaminobenzidine (DAB) was used for color development, and hematoxylin was used for counterstaining. Negative control slides processed without primary antibodies were included for each staining. All the slides were coded so that the investigator was blinded to staining for each slide and graded them according to the following scale: - no staining, + slight, ++ medium, +++ strong.

Statistical analysis: Statistical analysis of results was performed by one-way analysis of variance (ANOVA) followed by post hoc Duncan multiple comparisons tests. Group differences were declared significant at $\mathrm{p}<0.05$.

\section{Results}

Body weight gain: The body weight gain was lower in the CAP-treated group $(108.6 \mathrm{~g} \pm 3.2)$ but no significant differences $(\mathrm{P}>0.05)$ were observed in comparison to the control group $(115.2 \mathrm{~g} \pm 2.6)$ and vehicle group $(119.6 \mathrm{~g} \pm$ 2.2). No mortality was observed during the experimental period and the appearance of all the animals was indicative of good health. 
Histology: In all groups, the wall of duodenum was composed of tunica mucosa, submucosa, tunica muscularis and tunica serosa. In CAP-treated group, the duodenal villi were almost more uniform (finger- like villi) compared with vehicle and control groups' villi (Figure 1).

Morphometric analysis: The maximum heights of the villi were observed in the CAP treated group $(624.42 \mu \mathrm{m} \pm 12.51)$ and were significantly different $(\mathrm{p}<0.05)$ from the control group $(398.87 \mu \mathrm{m} \pm 17.85)$ and vehicle group $(521.00 \mu \mathrm{m} \pm 12.28)$ (Figure $2 \mathrm{~A})$. In this study, the depth of crypt was found to be longer in the CAP treated group $(186.03 \mu \mathrm{m} \pm 1.09)$ than the control group $(183.99 \mu \mathrm{m} \pm 1.09)$ and vehicle group $(185.14 \mu \mathrm{m} \pm 1.07)$. However, our results did not show significant differences in the crypts depth of the duodenum mucosa at the end of 20 experiment days in all groups ( $\mathrm{p}>0.05$ ) (Figure 2B).

Immunohistochemistry: The cellular localization of SP in the duodenum was ascertained by labelled streptavidin biotin complex method. In this protocol, a positive reaction is characterized by the deposition of a brown precipitate at the site of the antigen-antibody interaction. The intensities of SP immune staining as semiquantitative evaluated were shown Table. It is notable that,

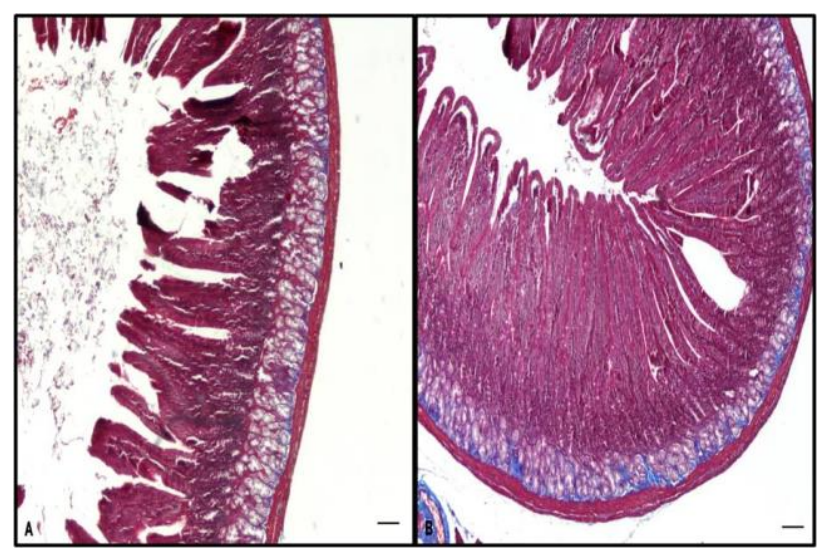

Figure 1. Transverse sections of duodenum from control (A) and CAP treated (B) groups. Crossman's triple stained. Bar: $100 \mu \mathrm{m}$. Şekil 1. Kontrol (A) ve CAP uygulanan grupların (B) duodenum enine kesitleri. Crossman'ın üçlü boyaması. Bar: $100 \mu \mathrm{m}$.
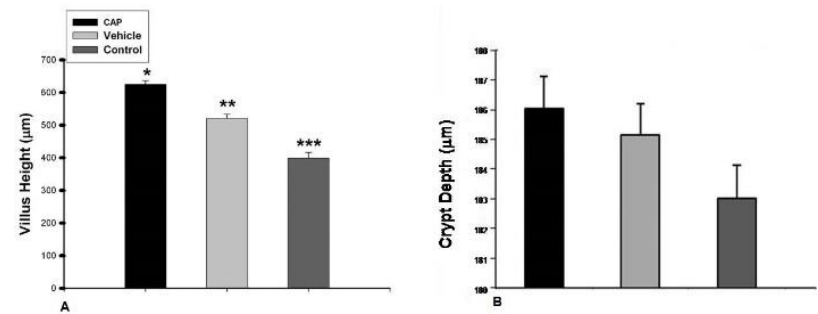

Figure 2. Bar graphs represent differences in villus height (A) and crypt depth (B) among groups (Data reported as mean $\pm \mathrm{SD}$ ). Asteriks (*) located above each bar represent statistically differences $(\mathrm{p}<0.05)$.

Şekil 2. Gruplarda villus yüksekliği (A) ve kript derinliği (B). Asteriks $(*)$ gruplar arasındaki istatiksel önemi $(\mathrm{p}<0.05)$ göstermektedir. in all positive immunoreactions were found intracytoplasmic location and nuclear staining was not observed. SP immunoreactions were seen in epithelial layers of villi, Lieberkühn crypts, Brunner's glands, tunica muscularis layer and the neurons of the myenteric plexus of the duodenum. The immunoreaction of SP was strong both in vehicle and CAP treated group's surface epithelium but slight reaction was observed in control group's surface epithelium (Figure 3). In Brunner's glands, the immunoreactions in experimental group were stronger than the vehicle group. In addition that, the immunoreactions in control group's Brunner glands were very slightly (Figure 4). In Lieberkühn crypts, immunoreactions were observed moderate in experimental group (Figure 4) and slight in vehicle group, but no reaction was observed in control group. In all groups, strong SP immunoreaction was detected in the neurons of the myenteric plexus. The differences in the expression of SP immunoreactions between the groups in the mentioned regions are presented in Table.

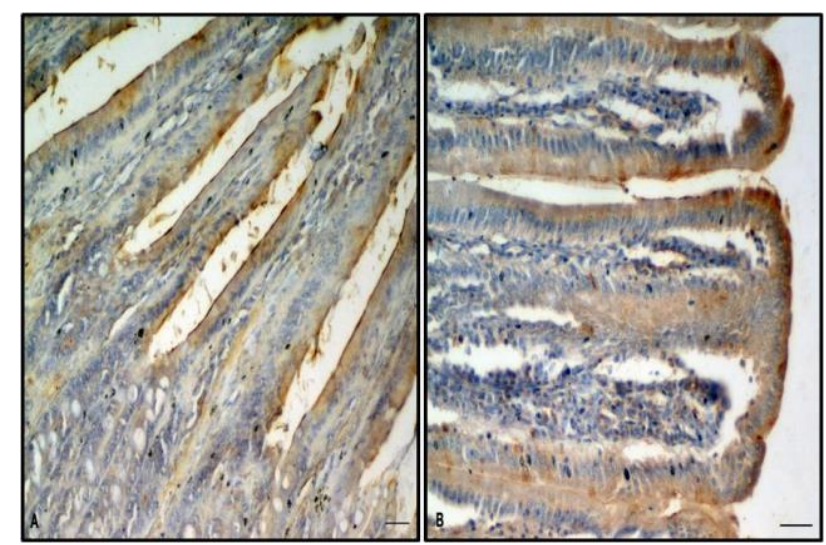

Figure 3. Immunostainings of SP in surface epithelium of control (A) and CAP treated (B) groups. Bar: $25 \mu \mathrm{m}$

Şekil 3. Kontrol (A) ve CAP uygulanan grupların (B) yüzey epitelindeki SP immun boyanmasi. Bar: $25 \mu \mathrm{m}$.

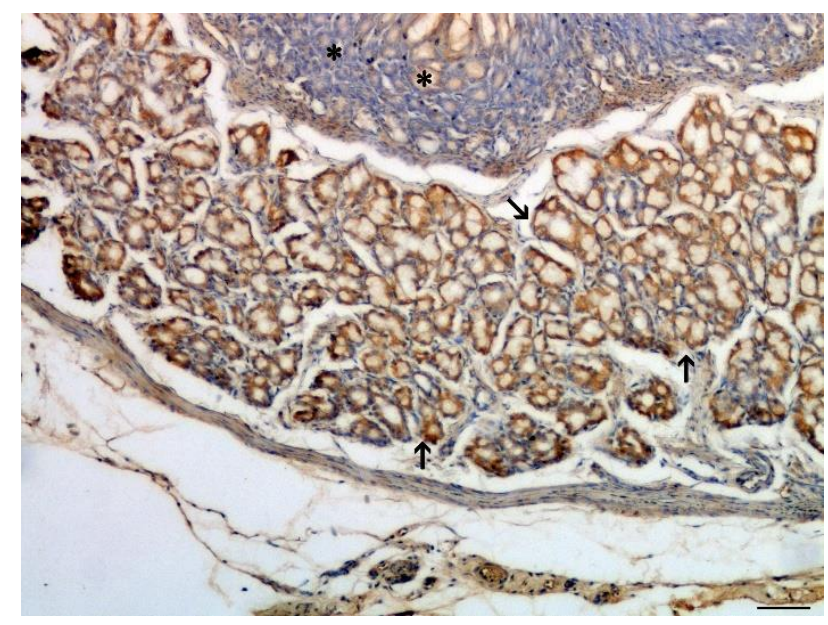

Figure 4. Immun reactions of SP in Brunner's glands (arrows) and Lieberkühn crypts $\left({ }^{*}\right)$ of CAP treated group. Bar: $50 \mu \mathrm{m}$. Şekil 4. CAP uygulanan grupta Brunner bezleri (arrows) ve Lieberkühn kriptlerinde (*) SP immun reaksiyonu. Bar: $50 \mu \mathrm{m}$. 
Table: Semiquantitative observations of the SP immunoreactivity in the rat duodenum. Tablo: Rat duodenumunda SP immun reaksiyonun semikantitatif incelemeleri.

\begin{tabular}{lccc}
\hline \multicolumn{1}{c}{ Duodenum } & Control & CAP-treated & Vehicle \\
\hline Surface epithelium & + & +++ & +++ \\
Brunner's gland & + & +++ & ++ \\
Lieberkühn crypts & - & ++ & + \\
Tunica muscularis & + & ++ & ++ \\
Myenteric plexus & +++ & +++ & +++ \\
\hline
\end{tabular}

Intensity of reaction: - no staining, + slight, ++ moderate, +++ strong.

\section{Discussion and Conclusion}

The gastrointestinal tract is known to be rich in neurons. These sensory neurons are primary afferents and have several important physiological functions in the gastrointestinal tract $(11,24)$. A rich plexus of nerve fibers containing sensory neuropeptides such as SP and CGRP is distributed throughout the gastric mucosa $(14,43)$. SP, an 11-amino acid neuropeptide was originally isolated and purified by Chang and Leeman (7) from bovine pituitary glands. The effects of SP are mediated by three different G-protein-coupled receptors (GPCRs), namely neurokinin (NK)-1, 2, and 3. SP binds with high affinity to NK-1 receptor (NK-1R), and with low affinity to NK-2 and 3 receptors. NK-1 receptors are present in both small intestine and colon of animals and humans and are localized in a variety of cells, including nerves, smooth muscle, immune cells, glands, endothelial cells, as well as epithelial cells $(39,41)$. Systemic high dose capsaicin treatment, which depletes SP in sensory neurons, however, caused only approximately 50\% decrease in tissue SP levels (9). Although effects of high dose capsaicin are well established, effects of repeated exposure to low doses are unknown. Hence, we examined the effects of low-dose CAP $(0.5 \mathrm{mg} / \mathrm{kg})$ daily for 20 days on SP immunohistochemical expression and histomorphometric properties of duodenum in rat.

In the present study, immunohistochemical and histomorphometric evaluation demonstrated that treatment with a low-dose CAP $(0.5 \mathrm{mg} / \mathrm{kg})$ was increased the expression of SP and positively affected on intestinal morphology. Numerous studies support the view that CAP reduces the amount of body weight gain $(28,45)$. It was reported that the effects of CAP on body weight change are especially based on lipid metabolism $(26,35)$. CAP increases carbohydrate metabolism and the activity of liver enzymes, stimulates lipid metabolism, and makes lipid mobilization from fatty tissue easier (31). CAP is used in the treatment of obesity due to its stimulatory effect (29). In our study, the weight loss observed in CAP treatment group was consistent with those observed by other investigators $(36,49)$.

The small intestine, especially crypts and villi of the absorptive epithelium, plays a significant role of nutrient digestion and assimilation (51). An elongation of villus increases the surface area for nutrient absorption. CAP was also stated to increase the absorption of substances in small intestine (50). In the present study, low dose CAP did not alter the depth of crypt in the duodenum but the height of the villus was higher than those in the other group. These results can be related the functional activity of increased SP following low dose CAP treatment which is considered to promote proliferation and cellular migration of the intestinal mucosa cells.

In the present study, we also demonstrated the expression of SP in the rat duodenum in paraffin sections by immunohistochemical technique. SP observed immunoreactivity in the surface epithelial cells of the villi, the Brunner's glands, crypts, smooth muscles, and neurons of the myenteric plexus of the duodenum. Similar to our findings, previous investigators have shown that immunoreaction of SP have been described in the epithelium of the small and large intestine of several species, including man $(27,44)$. SP has been shown to have a wide variety of cellular effects, including stimulation of calcium release (3), induction of endothelial cells to produce nerve growth factor (NGF) $(3,5)$, stimulation of endothelial and epithelial cell growth (3, $40)$, anion secretion on epithelial cells $(33,38)$. On the other hand, Hoffmann et al. (15) showed that stimulation of primary afferents in the rat colon by CAP induced an increase in mucosal epithelial cell proliferation. This effect was abolished by sensory desensitization or application of specific antagonists to SP. In our study, increased of SP following chronic low dose CAP treatment might be significant in epithelial cell functions and in modulating of digestive physiology. But, in our study, the intensity of immunoreactivity was similarly in the vehicle and the CAP treated group. It is well known that stressful conditions alter neuropeptide content. It was previously shown that isolation stress for $24 \mathrm{~h}$ increased SP levels in the central nervous system (4). Our previous study also observed that SP level was increased in the skin samples of the vehicle group by acetic acid extraction (10). Thus, we thought that increased SP immunoreaction in the vehicle group may be due to handling-injection stress.

We also determined that, SP immunoreaction was found in Brunner's gland. The Brunner's gland secretions were important both in normal digestive function and in mucosal protection and healing. In the present study, the immunoreaction to the SP was strong in the Brunner's glands of the CAP treated group, whereas SP immunoreactivity was weak in the control groups. Moore 
et al. (34) demonstrated that multiple hormonal (such as gastrin, vasoactive intestinal polypeptide and secretin) inflammatory, and neuroendocrine agents activate Brunner's glands. In our previous study, VR1 immunoreaction was observed in the Brunner's glands of the CAP treated groups (52). CAP is highly specific for VR1 and has been shown to cause SP release (18). However, this probably is increased release of SP from primary sensory neurons via stimulation of VR1 receptors resulting in repeated low dose CAP treatment. Thus, CAP may also play a role in the regulation of mucosal healing and intestinal mucosecretion by increased Brunner's gland secretions. In the present study, the immunoreactions of SP also observed in the longitudinal muscle and myenteric plexus of the duodenum. Our immunohistochemical findings of SP localization are in agreement with the previous reports on the distribution of SP throughout the myenteric plexus and the external muscle layers. Previous investigators have shown that SP immunoreactivity has been identified in extrinsic sensory neurons (32), and in intrinsic enteric neurons of the myenteric and submucosal plexuses (46). In the other hand, SP specific receptor, NK1r was detected in myenteric and submucosal neurons of the duodenum, jejunum, ileum, and colon and in myenteric neurons of the stomach (13). As Holzer-Petsche et al. (17) demonstrated that these results are consistent with the data showing that capsaicin elicits contraction and relaxation of smooth muscle in the rat duodenum. Expressed SP by neurons in the myenteric plexus might also contribute to the development of enhanced intestinal motility and secretion.

In conclusion, our results demonstrate that, low dose CAP treatment continuously administered for 20 days did not produce degeneration of the CAP sensitive nerve endings. However, CAP was markedly stimulated expression of SP and also induced morphological changes in the duodenum.

\section{Acknowledgements}

This work was supported by a grant from TÜBITAK-TOVAG (The scientific and technological research council of Turkey; project no: 104 O 372).

\section{References}

1. Abdel-Salam OME, Debreceni A, Mózsik GY, et al. (1999): Capsaicin-sensitive afferent sensory nerves in modulating gastric mucosal defense against noxious agents. J Physiol, 93, 443-454.

2. Abdel-Salam OME, Szolcsányi J, Barthó L, et al. (1994): Sensory nerve-mediated mechanisms, gastric mucosal damage and its protection: A critical overview. Gastroprotection, 2, 4-12.

3. Ansel JC, Kaynard AH, Armstrong CA, et al. (1996): Skin-nervous system interactions. J Invest Dermatol, 106, 198-204.

4. Brodin E, Rosen A, Schott E, et al. (1994): Effects of sequential removal of rats from a group cage, and of individual housing of rats, on substance $P$, cholecystokinin and somatostatin levels in the periaqueductal grey and limbic regions. Neuropeptides, 26, 253-60.

5. Burbach GJ, Kim KH, Zivony AS, et al. (2001): The neurosensory tachykinins substance $P$ and neurokinin $A$ directly induce keratinocyte nerve growth factor. J Invest Dermatol, 117, 1075-1082.

6. Caterina MJ, Schumacher MA, Tominaga M, et al. (1997): The capsaicin receptor: A heat activated ion channel in the pain pathway. Nature, 389, 816-824.

7. Chang MM, Leeman SE (1970): Isolation of asialogogic peptide from bovine hypothalamic tissue and its characterization as substance P. J Biol Chem, 245, 47844790.

8. Chard PS, Bleakman D, Savidge JR, et al. (1995): Capsaicin-induced neurotoxicity in cultured dorsal root ganglion neurons: Involvement of calcium-activated proteases. Neuroscience, 65, 1099-1108.

9. Erin N, Clawson GA (2004): Parameters affecting substance $P$ measurement in heart, lung, and skin. Biotechnique, 232, 234-236.

10. Erin N, Zik B, Sarigül M, et al. (2009): The effects of chronic low-dose capsaicin treatment on substance P levels. Regul Pept, 153, 83-87.

11. Faussone-Pellegrini MS, Taddei A, Bizzoco E, et al. (2005): Distribution of the vanilloid (capsaicin) receptor type 1 in the human stomach. Histochem Cell Biol, 124, 61-68.

12. Geppetti P, Trevisani M (2004): Activation and sensitization of the vanilloid receptor: Role in gastrointestinal inflammation and function. Br J Pharmacol, 141, 13131320.

13. Grady EF, Baluk P, Bohm S, et al. (1996): Characterization of antisera specific to NK1, NK2, and NK3 neurokinin receptors and their utilization to localize receptors in the rat gastrointestinal tract. J Neurosci, 16, 6975-6986.

14. Green T, Dockray GJ (1987): Calcitonin gene-related peptide and substance $P$ in afferents to the upper gastrointestinal tract in the rat. Neurosci Lett, 76, 151-156.

15. Hoffmann P, Mazurkiewicz J, Holtmann G, et al. (2002): Capsaicin-sensitive nerve fibres induce epithelial cell proliferation, inflammatory cell immigration and transforming growth factor-alpha expression in the rat colonic mucosa in vivo. Scand J Gastroenterol, 37, 414-422.

16. Holzer P, Sametz W (1986): Gastric mucosal protection against ulcerogenic factors in the rat mediated by capsaicin-sensitive afferent neurons. Gastroenterology, 91, 975-981.

17. Holzer-Petsche U, Seitz H, Lembeck F (1989): Effect of capsaicin on gastric corpus smooth muscle of the rat in vitro. Eur J Pharmacol, 162, 29-36.

18. Holzer P (1991): Capsaicin: Cellular targets, mechanisms of action, and selectivity for thin sensory neurons. Pharmacol Rev, 43, 143-201.

19. Holzer P, Livingston EH, Saria A, et al. (1991): Sensory neurons mediate protective vasodilation in rat gastric mucosa. Am J Physiol, 260, 363-370.

20. Holzer P (1998): Neural emergency system in the stomach. Gastroenterology, 114, 823-839.

21. Höckerfelt U, Franzon L, Forsgren S (2001): Substance $P\left(N K_{1}\right)$ receptor in relation to substance $P$ innervation in rat duodenum after irradiation. Regul Pept, 98, 115-126. 
22. Huang ZL, Mochizuki T, Watanabe H, et al. (1999): Activation of sensory nerves participates in stress-induced histamine release from mast cells in rat. Neurosci Lett, 270 , 181-184.

23. Jackson P, Blythe D (1993): Immunolabelling techniques for light microscopy. 15-43 In: Beesley JE (Ed), Immunocytochemistry. Oxford University Press, New York.

24. Kang JY, Alexander B, Math MV, et al. (1993): The effect of chilli and its pungent ingredient capsaicin on gastrointestinal transit in the rat. J Gastroenterol Hepatol, 8, 513-516.

25. Kang JY, Teng CH, Wee A, et al. (1995): Effect of capsaicin and chilli on ethanol induced gastric mucosal injury in the rat. Gut, 36, 664-669.

26. Kawada T, Hagihara KI, Iwai K (1986): Effects of capsaicin on lipid metabolism in rats fed a high fat diet. Journal Nutr, 116, 1272-1280.

27. Keast JR, Furness JB, Costa M (1985): Distribution of certain peptide containing nerve fibers and endocrine cells in the gastrointestinal mucosa of five mammalian species. $\mathrm{J}$ Comp Neurol, 236, 403-422.

28. Kempaiah RK, Srinivasan K (2004): Influence of dietary curcumin, capsaicin and garlic on the antioxidant status of red blood cells and the liver in high fat fed rats. Ann Nutr Metab, 48, 314-320.

29. Kim C, Robert AM, Joshua IG (1995): Differences in the capsaicin-induced dilation of arterioles and venules in rat striated muscle. J Pharmacol Exp Ther, 273, 605-610.

30. Lippe IT, Pabst MA, Holzer P (1989): Intragastric capsaicin enhances rat gastric acid elimination and mucosal blood flow by afferent nerve stimulation. $\mathrm{Br} \mathrm{J}$ Pharmacol, 96, 91-100.

31. Lobb D (2009): Expression and actions of transforming growth factors during human follicular development. Fertil Steril, 92, 1080-1084.

32. Maggi CA, Patacchini R, Giachetti A, et al. (1990): Tachykinin receptors in the circular muscle of the guineapig ileum. Br J Pharmacol, 101, 996-1000.

33. Mathison R, Davison JS (1989): Regulation of epithelial ion transport in the jejunal mucosa of the guinea pig by neurokinins. Life Sci, 45, 1057-1064.

34. Moore BA, Kim D, Vanner S (2000): Neural pathways regulating Brunner's gland secretion in guinea pig duodenum in vitro. Am J Physiol Gastrointest Liver Physiol, 279, 910-917.

35. Naponitaya W (1973): Long-term effects of capsaicin on fat absorption and the growth of the rat. Growth, 37, 269279.

36. Ozer A, Zik B, Erdost H, et al. (2006): Histological investigations on the effects of feeding with a diet containing red hot pepper on the reproductive system organs of the cock. Turk J Vet Anim Sci, 30, 7-15.

37. Park JS, Choi MA, Kim BS, et al. (2000): Capsaicin protects against ethanol-induced oxidative injury in the gastric mucosa of rats. Life Sci, 67, 3087-3093.

38. Parsons AM, Seybold VS, Chandan R, et al. (1992): Neurokinin receptors and mucosal ion transport in porcine jejunum. J Pharmacol Exp Ther, 261, 1213-1221.

39. Pothoulakis C, Castagliuolo I, Leeman SE, et al. (1998): Substance $P$ receptor expression in intestinal epithelium in
Clostridium difficile toxin A enteritis in rats. Am J Physiol, 275, 68-75.

40. Reid TW, Murphy CJ, Iwahashi CK, et al. (1993): Stimulation of epithelial cell growth by the neuropeptide substance P. J Cell Biochem, 52, 476-485.

41. Renzi D, Pellegrini B, Tonelli F, et al. (2000): Substance $P$ (neurokinin-1) and neurokinin A (neurokinin-2) receptor gene and protein expression in the healthy and inflamed human intestine. Am J Pathol, 157, 1511-1522.

42. Shanahan F (1998): Enteric neuropathophysiology and inflammatory bowel disease. Neurogastroenterol Motil, 10, 185-187.

43. Sharkey KA, Williams RG, Dockray GJ (1984): Sensory substance $P$ innervation of the stomach and pancreas. Demonstration of capsaicin-sensitive sensory neurons in the rat by combined immunohistochemistry and retrograde tracing. Gastroenterology, 87, 914-21.

44. Sokolski KN, Lechago J (1984): Human colonic substance P-producing cells are a separate population from the serotonin-producing enterochromaffin cells. J Histochem Cytochem, 32, 1066-1074.

45. Srinivasan MR, Satyanarayana MN (1989): Effect of capsaicin on skeletal muscle lipoprotein lipase in rats fed high fat diet. Indian J Exp Biol, 27, 910-2.

46. Sundler F, Hakanson R, Larsson LI, et al. (1977): Substance $P$ in the gut: Immunohistochemical and immunocytochemical study of distribution and development. 59-65, In: von Euler US, Pernow B (Eds), Substance P. Raven Press, New York.

47. Szolcsanyi J, Bartho L (2001): Capsaicin-sensitive afferents and their role in gastroprotection: an update. $\mathrm{J}$ Physiol, 95, 181-188.

48. Takeuchi K, Ueshima K, Matsumoto J, et al. (1992): Role of capsaicin- sensitive sensory nerves in acid-induced bicarbonate secretion in rat ispepstomach. Dig Dis Sci, 37, 737-743.

49. Tutuncu S, Ozfiliz O (2011): Distribution of the vanilloid (capsaicin) receptor type 1 in the capsaicin treated rat ovaries on different sexual development periods. Revue Méd Vét, 162, 460-467.

50. Udupihille M (1993): The effect of capsaicin on the small intestinal absorption of glucose and alanine in the rat. Indian J Physiol Pharmacol, 37, 59-62.

51. Wang JX, Peng KM (2008): Developmental morphology of the small intestine of African ostrich chicks. Poult Sci, 87, 2629-2635.

52. Zik B, Ozguden C, Tutuncu S et al. (2007): Expression of vanilloid receptor-1 in the duodenum of the capsaicin treated rat. Bull Vet Inst Pulawy, 51, 149-153.

Geliş tarihi: 31.03.2015 / Kabul tarihi: 28.12.2015
Address for correspondence:
Prof. Dr. Berrin ZIK
Uludă̆ University, Faculty of Veterinary Medicine, Department of Histology and Embryology, Bursa, Turkey. e-mail:bzik@uludag.edu.tr 